Marianne Van Remoortel, “A Catalogue of Coleridge's 'Great Circulating Library'," Notes and Queries 57.2 (2010): 210-11.

\title{
A CATALOGUE OF COLERIDGE'S 'GREAT CIRCULATING LIBRARY’
}

In a notebook entry for March 1832, Coleridge recalls that his childhood appetite for reading was gratified when a stranger gave him a ticket for 'a great Circulating Library in King's Street, Cheapside' and he 'read thro' the whole Catalogue, folios and all-whether I understood them or did not understand them-running all risks, in skulking out, to get the two Volumes which I was entitled to have daily-Conceive what I must have been at $14[\ldots]^{\prime} .^{1}$ J. B. Beer identified this library in 1956 as John Boosey's City Library at 39, King Street. More recently, Duncan Wu has pointed to an advertisement in two 1793 issues of the Morning Post, in which Boosey, who had apparently thought of closing down his business, proudly announces its continuation under somewhat different terms. ${ }^{2}$

While Beer thought it 'unlikely that any catalogue [...] still survives' ${ }^{3}$, at least one copy has been preserved. The Biblioteca de Catalunya in Barcelona, Spain, holds a copy of A New Catalogue of the Circulating Library at No. 39, King Street, Cheapside (BerRes. $86-8^{\circ}$ ) by John Boosey, Bookseller. With 9,259 catalogued titles, Boosey's was one of the largest circulating libraries in late eighteenth-century London. The title page is undated, but a dated inscription in ink on the front flyleaf and the publication details

\footnotetext{
${ }^{1}$ Samuel Taylor Coleridge. The Notebooks of Samuel Taylor Coleridge, eds. Kathleen Coburn and Anthony John Harding (Princeton, 2002), V, 6675.

2 Duncan Wu, 'Coleridge's “Great Circulating Library”: A Footnote', Notes and Queries, xl (1993), 470.

33. B. Beer, 'Coleridge's “Great Circulating Library”', Notes and Queries, n.s. iii (1956), 264.
} 
of the periodicals listed in the catalogue suggest publication in January 1787 , when Coleridge was fourteen and a student at Christ's Hospital. Consisting of a main section and two appendices, the catalogue provides an update as well as a compilation of earlier versions. The main section contains 7,953 items and, if we may again rely on the periodicals, was first published in 1781, the year before Coleridge entered Christ's Hospital. The two appendices of 807 and 499 items must have been added later, in 1785 and 1787 respectively, allowing us some insight into the books that became available to him during his student years. All titles are further grouped by subject matter, language and format. A quick count reveals that more than 60 percent are non-fictional works on history, travel, science, arts, philosophy and religion, in addition to various tracts, letters and periodicals. Books in French occupy a segment of about 12 percent. English poetry, plays, romances and novels make up a quarter of the titles in 1781. The appendices, however, show a steady rise in the percentage of fictional and poetical works from just below 30 percent of the new titles in 1785 to 40 percent 1787.

In his Biographia Literaria Coleridge wrote:

At a very premature age, even before my fifteenth year, I had bewildered myself in metaphysicks, and in theological controversy. Nothing else pleased me. History, and particular facts, lost all interest in my mind. Poetry [...] itself, yea novels and romances, became insipid to me. ${ }^{4}$

With the discovery of this catalogue, it has now become possible to gain a more precise knowledge of the books that shaped Coleridge's fascination with metaphysics

\footnotetext{
${ }^{4}$ Samuel Taylor Coleridge. Biographia Literaria, eds. James Engell and W. Jackson Bate (Princeton, 1983), I, 15-16.
} 
and theology in the 1780s, of the gothic romances that influenced his early writings, of the works that formed his strong opinions on women writers, and of the poetry that he read before his encounter with Bowles's sonnets. In brief, as Beer put it in his note: '[I]f [a catalogue of Boosey's library] came to light [...] we should have a very clear and detailed guide to Coleridge's adolescent reading.'

Ghent University 